\title{
Practical $\mathrm{CO}_{2}$ monitor- ing in anaesthesia
}

Richard L. Knill MD FRCPC

"Over the oxygen supplies of the body, carbon dioxide spreads its protective wings."

Samson Wright, circa 1955.

The single most important hazard of anaesthesia is hypoxic injury or death that arises from accidents with equipment or critical complications of the respiratory, cardiovascular or metabolic systems (e.g., oesophageal intubation, apnoea, severe circulatory depression, malignant hyperthermia). Most of these complications immediately and dramatically alter $\mathrm{CO}_{2}$ delivery to the lungs by the circulation and/or $\mathrm{CO}_{2}$ clearance from the lungs by ventilation. Hence, monitoring the airway $\mathrm{CO}_{2}$ has been considered a useful way to detect them. Indeed, the employment of airway $\mathrm{CO}_{2}$ monitoring has become a standard of anaesthetic care. (The current CAS Guidelines "require" the use of a $\mathrm{CO}_{2}$ monitor in all "intubated patients.")

The primary purpose of this presentation is to review airway $\mathrm{CO}_{2}$ monitoring as a means of detecting critical complications of anaesthesia. A secondary purpose is to consider other ways in which this monitoring system can facilitate anaesthetic care. Further detailed information on this subject can be found elsewhere. ${ }^{1-5}$

\section{Technology}

To monitor airway $\mathrm{CO}_{2}$ requires a system that (1) samples airway gas continuously, (2) performs a rapid analysis of its $\mathrm{CO}_{2}$ content and (3) provides both a breath-bybreath waveform of the instantaneous $\mathrm{CO}_{2}$ level and a digital reading of the measured end-tidal $\mathrm{CO}_{2}$ tension.* "Capnography" refers to the process that generates the $\mathrm{CO}_{2}$ waveform, "capnometry" to the process that produces the end-tidal $\mathrm{CO}_{2}$ tension. The display of both can be called a "capnogram."

The most commonly employed method of analysis is infrared (IR) spectrophotometry using a wavelength of infrared light that is maximally absorbed by $\mathrm{CO}_{2}$. Errors may be introduced by the effects of carrier gases $\left(\mathrm{N}_{2} \mathrm{O}\right.$, $\mathrm{O}_{2}$, water vapour, drift, changes in sample cell pressure and temperature, as well as extraneous contaminants. ${ }^{5,6}$ However, nearly all IR analyzers incorporate techniques to prevent, minimize or automatically compensate for the influence of these factors. Less commonly, $\mathrm{CO}_{2}$ is an-

*Throughout this review, $\mathrm{CO}_{2}$ levels will be referred to in terms of tension ( $\mathrm{mmHg}$ ) rather than concentration (\%). alyzed by mass spectrometry, a method which is inherently less subject to error - but more costly and more logistically difficult to employ.

Airway gas is usually sampled by the so-called "sidestream" technique, in which gas is drawn continuously from the airway to the analyzer through a small bore tube at a rate of $50-250 \mathrm{ml} \cdot \mathrm{min}^{-1}$. The size of the sampling tube, the volume of the analyzer cell and the rate of sampling are all selected to minimize the time of response, preserve the waveform and ensure the accuracy of the end-tidal $\mathrm{CO}_{2}$ tension. In the less common "mainstream" technique, all airway gas flows through a heated IR analyzer placed directly in the patient's airway system. To obtain adequate "clean" samples of inspired and expired gas with either technique, it is essential that the sampling site be as close as possible to the airway opening, well away from both the fresh gas outlet and the inspired/expired gas interface in the circuit. It is also critical that the sampling system be free of leaks.

Each sampling technique has its own special problems. The tiny sampling tube used with the sidestream technique is prone to occlusion by secretions or water condensate. All sidestream systems include filters, water traps, water permeable catheters and/or automatic purging pumps to prevent or manage this problem. The withdrawal of airway gas by the sidestream technique increases the risk of diluting the sampled gas with fresh gas, especially with use of the Mapleson D or E circuit in infants. The mainstream IR analyzer adds mechanical dead space to the airway and is prone to contamination with airway secretions. It is also bulky and susceptible to damage.

\section{The normal capnogram}

At the beginning of expiratory flow (Figure), the gas appearing at the airway opening is dead space gas which generates no $\mathrm{CO}_{2}$ signal. As expiration proceeds, a front of $\mathrm{CO}_{2}$ containing alveolar gas arrives at the airway opening to cause an abrupt upstroke in the $\mathrm{CO}_{2}$ tracing. Following the alveolar front is pure alveolar gas that inscribes a horizontal or very slowly rising line called the "alveolar plateau." At the end of the plateau, corresponding to the end of expiratory flow, the tracing peaks at

From the Department of Anaesthesia, Faculty of Medicine, University of Western Ontario, London, Ontario. 


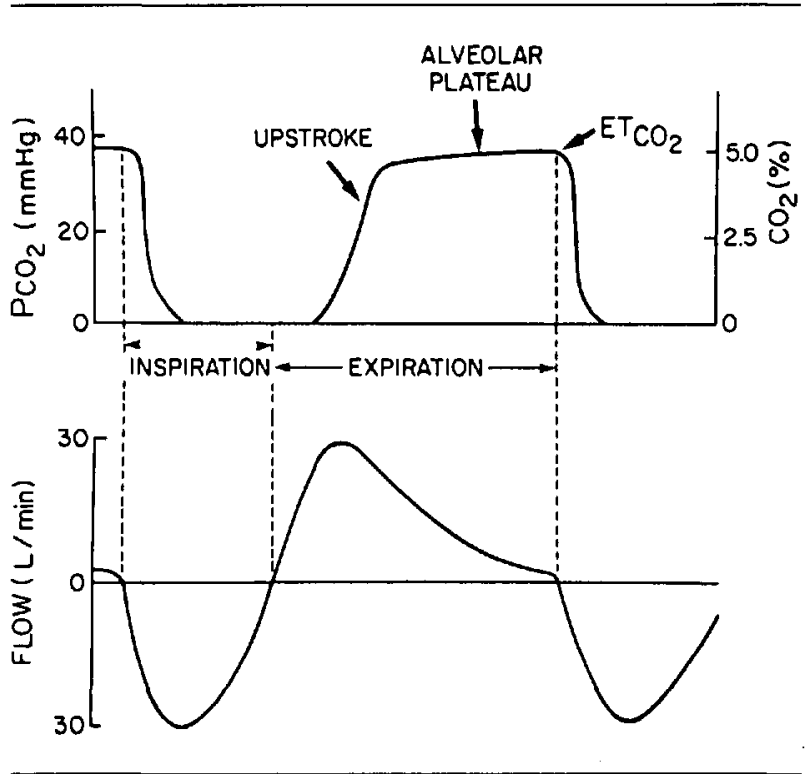

FIGURE Simultaneous record of airway carbon dioxide tension or concentration (upper graph) and airway gas flows (lower graph) through a single respiratory cycle.

a value called the end-tidal $\mathrm{CO}_{2}$ tension $(\mathrm{PETCO})$. With the commencement of inspiratory flow, the trace declines rapidly to zero.

The normal capnogram has four important characteristics - three qualitative and one quantitative. It is essential to appreciate each characteristic and what it represents.

$1 \mathrm{~A}$ representation of $\mathrm{CO}_{2}$ in expired gas. Expired $\mathrm{CO}_{2}$ is the end result of a series of physiologic processes which include the metabolic production of $\mathrm{CO}_{2}$, its circulatory transport to the lungs and alveolar ventilation.

2 An indication of no $\mathrm{CO}_{2}$ in inspired gas. The absence of inspired $\mathrm{CO}_{2}$ reflects those functions of the anaesthetic circuit that prevent rebreathing of $\mathrm{CO}_{2}$.

3 An expiratory $\mathrm{CO}_{2}$ waveform with a sharp upstroke and distinct alveolar plateau. These features are a function of ventilatory mechanics. The sharp upstroke depends upon an adequate early expiratory flow rate. The nearly horizontal plateau is contingent upon sufficient expiratory flow together with near synchronous emptying of different lung regions.

4 An end-tidal $\mathrm{CO}_{2}$ tension.* This quantitative variable is close to the alveolar and arterial $\mathrm{CO}_{2}$ tensions $\left(\mathrm{PACO}_{2}, \mathrm{PaCO}_{2}\right.$ respectively) but only when certain conditions obtain.

The $\mathrm{PeTCO}_{2}$ approximates the $\mathrm{PACO}_{2}$ if the end-tidal gas is a clean sample of mixed alveolar gas. This con-

*In most $\mathrm{CO}_{2}$ monitoring systems, the displayed end-tidal $\mathrm{CO}_{2}$ tension is actually the maximum expired $\mathrm{PCO}_{2}$. For practical purposes, the two can be considered synonymous. dition can be assumed only when the capnogram displays a typical alveolar plateau. (The absence of a plateau suggests a small tidal volume, fresh gas dilution of the expired gas and/or sampling too close to the inspired/expired gas interface.) The $\mathrm{PETCO}_{2}$ is also a guide to the $\mathrm{PaCO}_{2}$ if the end-tidal gas sample is derived from "ideal" alveoli (i.e., ventilated and perfused alveoli) without a contribution from alveolar dead space (i.e., ventilated but not perfused alveoli). In the context of anaesthesia, this additional condition can be assumed only for patients who are $<50 \mathrm{yr}$ of age, healthy and haemodynamically stable - where the PETCO $\mathrm{Pis}_{2}$ usually slightly less than $\mathrm{PaCO}_{2}$, but within $5 \mathrm{mmHg}{ }^{7}$ It cannot be assumed for older patients, sitting patients, those who suffer acute or chronic respiratory or cardiovascular disease, or who have systemic hypotension. ${ }^{8,9}$ In these latter circumstances, gas from alveolar dead space may considerably contaminate the end-tidal sample so that the $\operatorname{PETCO}_{2}$ value underestimates the $\mathrm{PaCO}_{2}$ substantially.

When the $\mathrm{PETCO}_{2}$ approximates the $\mathrm{PACO}_{2}$, it also reflects the determinants of $\mathrm{PACO}_{2}$. In a steady state, it is directly proportional to the rate of $\mathrm{CO}_{2}$ delivery to the alveoli $\left(\dot{\mathrm{V}} \mathrm{CO}_{2}\right)$ and inversely proportional to the total alveolar ventilation $\left(\dot{V}_{A}\right)$ as in the following relationship:

$\mathrm{PETCO}_{2} \simeq \mathrm{PACO}_{2}=\mathrm{k} \cdot \frac{\dot{\mathrm{V}} \mathrm{CO}_{2}}{\dot{\mathrm{VA}}_{\mathrm{A}}}$

where " $k$ " is a proportionality constant)

In an unsteady state, when either $\dot{\mathrm{V}} \mathrm{CO}_{2}$ or $\dot{\mathrm{V}}_{\mathrm{A}}$ is changing or has recently changed, this quantitative relationship no longer obtains. Nevertheless, the PETCO ${ }_{2}$ deviates and the direction and rate of the deviation reflect the direction and magnitude of the $\dot{\mathrm{V}}_{\mathrm{CO}_{2}}$ or $\dot{\mathrm{V}}_{\mathrm{A}}$ change.

\section{The abnormal capnogram}

There are four general abnormalities of the capnogram that may indicate a critical complication. Each relates to one of the characteristics described above. Each abnormality, its physiologic meaning and its potential causes must be understood (Table I).

1 The absence of $\mathrm{CO}_{2}$ in expired gas. This abnormality signifies little or no effective circulation and/or alveolar ventilation. During anaesthesia, this is usually due to an accident with equipment such as intubation of the oesophagus or a circuit disconnect, or a critical ventilatory event such as apnoea or airway obstruction. It also appears with cardiac arrest.

2 The presence of $\mathrm{CO}_{2}$ in inspired gas. Inspired $\mathrm{CO}_{2}$ appears normally with deliberately induced rebreathing in semi-closed circuits (e.g., the Bain use of the Mapleson D system). When inspired $\mathrm{CO}_{2}$ appears unexpectedly or in unexpected amounts, it indicates rebreathing due to a malfunction of the anaesthetic 
TABLE I The abnormal capnogram

\begin{tabular}{|c|c|c|}
\hline Capnogram abnormality & Physiologic meaning & Potential causes \\
\hline 1 Absence of expired $\mathrm{CO}_{2}$ & No effective circulation and/or ventilation & $\begin{array}{l}\text { Oesophageal intubation } \\
\text { Circuit disconnection } \\
\text { Apnoea } \\
\text { Total airway obstruction } \\
\text { Cardiac arrest }\end{array}$ \\
\hline 2 Presence of inspired $\mathrm{CO}_{2}$ & Rebreathing of exhaled $\mathrm{CO}_{2}$ & $\begin{array}{l}\text { Incompetent circuit valves } \\
\text { Exhausted } \mathrm{CO}_{2} \text { absorber } \\
\text { Low fresh gas flow in Mapleson A, D or E circuits }\end{array}$ \\
\hline $\begin{array}{l}3 \text { Deformed waveform } \\
\text { (a) Prolonged upstroke }\end{array}$ & Reduced expiratory flow & $\begin{array}{l}\text { Partial airway obstruction } \\
\text { Bronchospasm }\end{array}$ \\
\hline (b) Increased plateau slope & Asynchronous lung emptying & $\begin{array}{l}\text { COPD } \\
\text { Bronchospasm }\end{array}$ \\
\hline $\begin{array}{l}4 \text { Deviation of } \mathrm{PETCO}_{2} \\
\text { (a) } \mathrm{iPETCO}_{2}\end{array}$ & $\begin{array}{l}\text { IAlveolar ventilation } \\
1 \mathrm{CO}_{2} \text { delivery to alveoli }\end{array}$ & $\begin{array}{l}\text { Hypoventilation } \\
\text { Malignant hyperthermia } \\
\mathrm{CO}_{2} \text { absorbed at laparoscopy } \\
\text { Bicarbonate administration* } \\
\text { Release of limb tourniquet* }\end{array}$ \\
\hline (b) $\mathrm{PETCO}_{2}$ & $\begin{array}{l}\text { IAlveolar ventilation } \\
1 \mathrm{CO}_{2} \text { delivery to alveoli }\end{array}$ & $\begin{array}{l}\text { Hyperventilation } \\
\text { Hypothermia } \\
\text { Low-output circulatory failure } \\
\text { Pulmonary embolism }\end{array}$ \\
\hline
\end{tabular}

- Transient elevation of $\mathrm{PETCO}_{2}$ only.

circuit, such as an incompetent valve or an exhausted $\mathrm{CO}_{2}$ absorber in a circle system, or an inadequate fresh gas flow in a Mapleson D system.

3 Deformation of the expiratory $\mathrm{CO}_{2}$ waveform. A prolongation of the upstroke can indicate a reduced expiratory flow caused by upper airway obstruction or bronchospasm. An increase in the slope of the alveolar plateau can denote uneven lung emptying due to COPD or bronchospasm. Certain other alterations of the typical waveform do not necessarily reflect a problem - e.g., the "chaotic" or "truncated" waveforms associated with the shallow tidal volumes of spontaneous ventilation through a face-mask; the "camel-back" alveolar plateaus seen with mechanical ventilation in the lateral position; the "cardiogenic oscillations" observed with slow respiratory rates and the "Bain bump" with the Bain use of the Mapleson D circuit.

4 Deviations of the PETCO 2 . When the $\mathrm{PETCO}_{2}$ can be taken to approximate the $\mathrm{PACO}_{2}$, a progressive rise of $\mathrm{PETCO}_{2}$ suggests either alveolar hypoventilation or an increase in the delivery of $\mathrm{CO}_{2}$ to alveoli, as with malignant hyperthermia (see above). Conversely, a gradual reduction denotes alveolar hyperventilation or a decrease in $\mathrm{CO}_{2}$ transfer to alveoli, as with hypothermia or low-output circulatory failure. An abrupt reduction of $\mathrm{PETCO}_{2}$ suggests a sudden interruption of $\mathrm{CO}_{2}$ delivery to a proportion of alveoli by pulmonary embolism.

\section{Value of the capnogram in detecting critical complications}

The fact that a capnogram abnormality or finding can indicate a critical complication does not necessarily mean it has diagnostic value. Its usefulness in diagnosis depends upon (1) its sensitivity in detecting the complication (defined as the proportion of patients with the complication who display the capnogram finding), (2) its specificity (the proportion without the complication who show no capnogram sign), (3) its time of appearance (the speed with which the capnogram finding develops) and (4) its additional diagnostic value (diagnostic capability over and above that achievable by standard means). Although few data exist on the value of capnogram findings to detect any particular complication, certain reasonable qualitative inferences about sensitivity, specificity, etc., for various complications can be made. These will be considered for critical complications related to anaesthetic equipment, ventilation, circulation and metabolism (Table II).

\section{Oesophageal intubation}

The absence of a typical pattern of expired $\mathrm{CO}_{2}$ is an almost perfectly sensitive indicator of this event. (The 
TABLE II Diagnostic value of the capnogram in detecting critical complications

\begin{tabular}{|c|c|c|c|c|}
\hline Complication & Capnogram finding & Sensitivity/Specificity & Time of appearance & Additional diagnostic value \\
\hline \multicolumn{5}{|l|}{ Equipment } \\
\hline Oesophageal intubation & No expiratory $\mathrm{CO}_{2}$ & High/Low & Immediate & High \\
\hline Circuit disconnection & No expiratory $\mathrm{CO}_{2}$ & High/Law & Immediate & Moderate (back-up) \\
\hline Rebreathing malfunction & $\mathrm{CO}_{2}$ in inspired gas & High/High & Immediate & High \\
\hline \multicolumn{5}{|l|}{ Ventilation } \\
\hline Apnoea; total airway obst'n & No expiratory $\mathrm{CO}_{2}$ & High/Low & Immediate & Moderate (back-up) \\
\hline Partial airway obstruction & Prolonged upstroke & Moderate/? & Immediate & Low \\
\hline Hypoventilation & Progressive IPETCO & High/Moderate & Early & High \\
\hline \multicolumn{5}{|l|}{ Circulation } \\
\hline Cardiac arrest & Rapid loss of $\exp \mathrm{CO}_{2}$ & High/Low & Immediate & Low \\
\hline Low-output circ. failure & $\checkmark \mathrm{PETCO}_{2}$ & Moderate/Moderate & Early & Low \\
\hline Pulmonary air embolism & Abrupt $\mid$ PeTCO 2 & High/High & Immediate & High \\
\hline \multicolumn{5}{|l|}{ Metabolism } \\
\hline Malignant hyperthermia & Rapid IPETCO & High/Moderate & Early & High \\
\hline
\end{tabular}

Note: Estimates of sensitivity/specificity and additional diagnostic value are those of the author.

small aberrant $\mathrm{CO}_{2}$ waveforms that may appear transiently with ventilation of the oesophagus cannot be considered typical). ${ }^{10}$ In addition, this sign is immediately evident. What it lacks is diagnostic specificity - because other conditions abolish the expired $\mathrm{CO}_{2}$ signal (e.g., circuit disconnect, severe bronchospasm upon intubation, analyzer failure). Since the other indicators of oesophageal intubation are occasionally confusing or delayed in their development, " the potential added diagnostic value of a failure to detect expired $\mathrm{CO}_{2}$ is high.

\section{Circuit disconnect}

Loss of expired $\mathrm{CO}_{2}$ is also a perfectly sensitive and immediate sign of a circuit disconnection. Again, however, it is also nonspecific. Since clinical observations and/ or a low circuit pressure alarm reveal this problem quickly and reliably, the added value of the capnogram finding is primarily as a back-up indicator. ${ }^{12}$

\section{Rebreathing malfunctions of the anaesthetic circuit} Inspired $\mathrm{CO}_{2}$ in unexpected amounts is a highly sensitive, specific and immediate sign of rebreathing of $\mathrm{CO}_{2}-$ although it is not specific for any individual cause (Table I). No other clinical sign nor monitor can detect $\mathrm{CO}_{2}$ rebreathing nearly as well. Thus, the added diagnostic value is high.

\section{Apnoea: total airway obstruction}

Loss of the expired $\mathrm{CO}_{2}$ signal is a highly sensitive, immediate but nonspecific sign of these events. Since both appear to be reliably detected by clinical observations or by circuit pressure alarms during mechanical ventilation, this sign is useful mainly as a back-up.

\section{Hypoventilation}

When the $\mathrm{PETCO}_{2}$ can be taken as a guide to the $\mathrm{PACO}_{2}$ and $\mathrm{PaCO}_{2}$, a progressive increase in its level is a highly sensitive, moderately specific and quickly evident indicator of inadequate ventilation. When the $\mathrm{PETCO}_{2}$ approximates the $\mathrm{PACO}_{2}$ only, its sensitivity/specificity may be somewhat less. Since the clinical indicators of moderate hypoventilation are insensitive and nonspecific, the added diagnostic value is high.

\section{Cardiac arrest}

A rapid reduction of $\mathrm{PETCO}_{2}$ and loss of the expiratory $\mathrm{CO}_{2}$ signal over $30 \mathrm{sec}$ or so is a sensitive sign of cardiac arrest. However, this event should be detected more specifically and more quickly by other means. Where the $\mathrm{PeTCO}_{2}$ may prove valuable in this context is as a noninvasive monitor of the effectiveness of precordial compressions during resuscitation. In this setting, the level of $\mathrm{PETCO}_{2}$ corresponds to the magnitude of cardiac output (really the rate of $\mathrm{CO}_{2}$ delivery to the lungs). ${ }^{13}$

\section{Pulmonary air embolism}

An abrupt reduction of the $\mathrm{PETCO}_{2}$ is a highly sensitive, specific and immediate indicator of an air embolism. It is substantially more sensitive than standard cardiovascular signs (IBP, †CVP and ECG changes) and more appropriately sensitive than the extremely sensitive 
Doppler technique. ${ }^{14}$ Accordingly, its added diagnostic value is high.

\section{Malignant hyperthermia}

A rapid increase in $\mathrm{PETCO}_{2}$ is a highly sensitive and early sign that precedes the rise in body temperature and other clinical indicators. ${ }^{15,16}$ It is not highly specific since marked hypoventilation can also produce a rapidly increasing $\mathrm{PETCO}_{2}$ level - but the latter condition can usually be excluded. Hence, its added diagnostic value is high.

From this analysis of critical events, it can be inferred that airway $\mathrm{CO}_{2}$ monitoring has its greatest diagnostic value as a sensitive and rapid detector of oesophageal intubation, malfunctions of the anaesthetic circuit that cause $\mathrm{CO}_{2}$ rebreathing, hypoventilation, air embolism and malignant hyperthermia. It may also be a sensitive "second line" detector of circuit disconnects, total airway obstruction and apnoea. Notwithstanding these inferred benefits, the reader should recognize that there is as yet no proof that use of $\mathrm{CO}_{2}$ monitoring averts the adverse sequelae of these events (i.e., hypoxic injury and death) nor that it improves anaesthetic outcome.

\section{Other clinical applications}

Two characteristics of the capnogram, the expiratory waveform and the $\mathrm{PETCO}_{2}$, can facilitate other aspects of anaesthetic care.

The $\mathrm{CO}_{2}$ waveform can help identify certain noncritical ventilatory events such as "break-through" ventilatory effort during mechanical ventilation (indicated by the "curare cleft") and variation in spontaneous breathing patterns. Observation of the waveform is said to aid blind nasotracheal intubation. ${ }^{4}$

The $\mathrm{PETCO}_{2}$ can both simplify and improve the regulation of $\mathrm{PaCO}_{2}$ for a variety of purposes including (1) initiation and maintenance of controlled apnoea for mechanical ventilation, (2) weaning from mechanical ventilation, (3) implementation of compensation for acid base disturbances, and (4) management of increased intracranial pressure. When there is suspicion that a substantial difference between the $\mathrm{PETCO}_{2}$ and the $\mathrm{PaCO}_{2}$ may exist, the $\mathrm{PETCO}_{2}-\mathrm{PaCO}_{2}$ difference can be measured directly and taken into account.

\section{Conclusion}

The special value of airway $\mathrm{CO}_{2}$ monitoring is its potential to alert the clinician about a range of critical complications of anaesthesia. As a detector of several of these complications, it is both sensitive and rapidly responsive - but not specific and therefore not diagnostic by itself. Accordingly, the findings of airway $\mathrm{CO}_{2}$ monitoring (like those of all other monitoring systems) must always be interpreted in the context of clinical observation of the patient and other pertinent information.

\section{References}

1 Adams AP. Capnography and pulse oximetry. In: Atkinson RS, Adams AP (Eds.). Recent Advances in Anaesthesia and Analgesia, New York: Longman Inc., 1989, 155-75.

2 Lillie PE, Roberts JG. Carbon dioxide monitoring. Anaesth Intensive Care 1988; 16: 41-4.

3 Swedlow DB. Capnometry and capnography: the anesthesia disaster early warning system. Seminars in Anesthesia, 1986; 5: 194-205.

4 Bhavani-Shankar K, Moseley H, Kumar AY, Delph Y. Capnometry and Anaesthesia. Can J Anaesth 1992; 39: 617-32.

5 Carbon dioxide monitors. Health Devices 1986; 15: 255-85.

6 Raemer DB, Calalang I. Accuracy of end-tidal carbon dioxide tension analyzers. J Clin Monit 1991; 7: 195-208.

7 Nunn JF, Hill $D W$. Respiratory dead space and arterial to end-tidal $\mathrm{CO}_{2}$ tension difference in anesthetized man. $\mathbf{J}$ Appl Physiol 1960; 15: 383-9.

8 Hatle L, Rokseth $R$. The arterial to end-expiratory carbon dioxide tension gradient in acute pulmonary embolism and other cardiopulmonary disease. Chest 1974; 66: 352-7.

9 Eckenhoff JE, Enderby GEH, Larson A, Edridge A, Judevine $D E$. Pulmonary gas exchange during deliberate hypotension. Br J Anaesth 1963; 35: 750-9.

10 Sum-Ping ST, Mehta MP, Anderton JM. A comparative study of methods of detection of esophageal intubation. Anesth Analg 1989; 69: 627-32.

11 Birmingham $P K$, Cheney FW, Ward RJ. Esophageal intubation: a review of detection techniques. Anesth Analg 1986; 65: 886-91.

12 Myerson KR, Ilsley AH, Runciman WB. An evaluation of ventilatory monitoring alarms. Anaesth Intensive Care 1986; 14: 174-85.

13 Weil MH, Bisera J, Trevino RP, Rackow EC. Candiac output and end-tidal carbon dixoide. Crit Care Med 1985; 13: 907-9.

14 Edmonds-Seal J, Prys-Roberts C, Adams AP. Air embolism. A comparison of various methods of detection. Anaesthesia 1971; 26: 202-8.

15 Baudendistel L, Goudsouzian N, Coté C, Strafford M. End-tidal $\mathrm{CO}_{2}$ monitoring. Its use in the diagnosis and management of malignant hyperthermia. Anaesthesia 1984; 39: 1000-3.

16 Dunn CM, Maltry DE, Eggers GWN. Value of mass spectrometry in early diagnosis of malignant hyperthermia (Letter). Anesthesiology 1985; 63: 333. 


\section{R.L. Knill MD FRCPC}

\section{Le monitorage du $\mathrm{CO}_{2}$ : aspects pratiques}

"Over the oxygen supplies of the body, carbon dioxide spreads its protective wings."

Samson Wright, circa 1955

La lésion hypoxique et la mort demeurent les grandes préoccupations de l'anesthésiste spécialement lorsqu'elles sont causées par des défectuosités de matériel ou par des accidents d'origine respiratoire, cardiovasculaire ou métabolique (v.g. l'intubation oesophagienne, l'apnée, l'insuffisance circulatoire, l'hyperthermie maligne). Ces événements modifient de façon immédiate et spectaculaire le transport et l'élimination du $\mathrm{CO}_{2}$. Par conséquent, il semble logique qu'on essaye de les prévenir en monitorisant le $\mathrm{CO}_{2}$. C'est la raison pour laquelle ce monitorage fait maintenant partie des standards de l'anesthésie. (Les recommandations actuelles de la SCA rendent obligatoire l'usage du moniteur de $\mathrm{CO}_{2}$ pour tous les patients intubés.)

Le principal objectif de cette communication consistera à passer en revue le monitorage du $\mathrm{CO}_{2}$ utilisé pour la détection des complications critiques peranesthésiques. L'objectif secondaire sera de regarder en quoi cette technique améliore l'exercice de l'anesthésie. On trouvera ailleurs des renseignements plus complets sur ce sujet. ${ }^{1-5}$

\section{Technologie}

Le monitorage du $\mathrm{CO}_{2}$ exige un système 1) qui prélève des échantillons de gaz continuellement, 2) les analyse rapidement, 3) transmet instantanément le tracé, 4) et présente l'affichage numérique de la pression télé-expiratoire du $\mathrm{CO}_{2}$. qui génère la forme d'onde et "capnométrie " au processus qui produit la pression du $\mathrm{CO}_{2}{ }^{*}$ L'affichage de ces deux paramètres s'appelle " capnogramme ".

La méthode d'analyse la plus employée est la spectrométrie aux infra-rouges (IR) qui utilise l'absorption par le gaz carbonique d'un rayon lumineux infra-rouge. Le gaz vecteur $\left(\mathrm{N}_{2} \mathrm{O}, \mathrm{O}_{2}\right)$, la vapeur d'eau, le déplacement de la ligne de base, les changements de température de la cellule et les substances étrangères représentent les causes d'erreurs usuelles. ${ }^{5,6}$ Cependant la plupart des analyseurs incorporent des techniques qui anticipent, atténuent ou corrigent automatiquement ces facteurs.

*Toute mention du $\mathrm{CO}_{2}$ réfère ici à la pression plutôt qu’à la concentration.
Moins fréquemment, l'analyse se fait par spectrométrie de masse, méthode moins sujette aux erreurs mais plus coûteuse et moins facile d'utilisation.

L'échantillon de gaz est généralement prélevé par soutirage latéral: l'aspiration se fait continuellement des voies respiratoires à la cellule par une tubulure de petit calibre à un débit de $50-250 \mathrm{ml} \cdot \mathrm{min}^{-1}$. Le calibre de la tubulure, le volume de la cellule et le débit sont choisis de façon à minimiser le délai de la réponse. On utilise plus rarement l'analyse directe où tout le gaz expiré passe à travers un analyseur IR chauffé placé sur le trajet des gaz respiratoires. Pour obtenir des échantillons " propres " de gaz inspirés et expirés, avec l'une ou l'autre de ces méthodes, il est essentiel que le site d'échantillonnage soit proche des voies respiratoires, loin de l'orifice de sortie des gaz frais et loin de l'interface gaz inspirégaz expiré. Le système doit aussi être étanche.

Chacune des techniques d'analyse apporte ses problèmes. Avec le soutirage latéral, la fine tubulure est sujette à l'obstruction par les sécrétions ou la condensation de l'eau. Tous ces systèmes incorporent des filtres, des pièges à eau, des cathéters perméables avec ou sans pompe d'épuration. L'extraction des gaz par soutirage latéral augmente le risque ${ }^{\prime}$ de dilution de l'échantillon par les gaz frais, surtout avec un circuit Mapleson D ou E chez l'enfant. L'analyseur central augmente l'espace mort mécanique et peut être contaminé par les sécrétions. De plus, il est encombrant et fragile.

\section{Le capnogramme normal}

Au début de l'expiration (Figure), le gaz qui se présente aux voies respiratoires vient de l'espace mort et ne contient pas de $\mathrm{CO}_{2}$. A mesure que l'expiration progresse, un front de gaz alvéolaire, contenant du $\mathrm{CO}_{2}$ parvient aux voies respiratoires supérieures et provoque la montée soudaine (segment ascendant) de la ligne de base. A la suite de ce front, l'apparition du gaz alvéolaire pur qui se traduit par une ligne horizontale ou faiblement inclinée appelée " plateau alvéolaire ". Au bout du plateau, correspondant à la fin du débit expiratoire, le tracé atteint un sommet, la pression télé-expiratoire du $\mathrm{CO}_{2}\left(\mathrm{PETCO}_{2}\right)$. Au début de l'inspiration, le tracé retombe rapidement à zéro.

Le capnogramme normal présente quatre caractéristiques importantes, dont trois sont quantitatives et une qualitative. Il est essentiel de connaitre ce à quoi elles correspondent: 


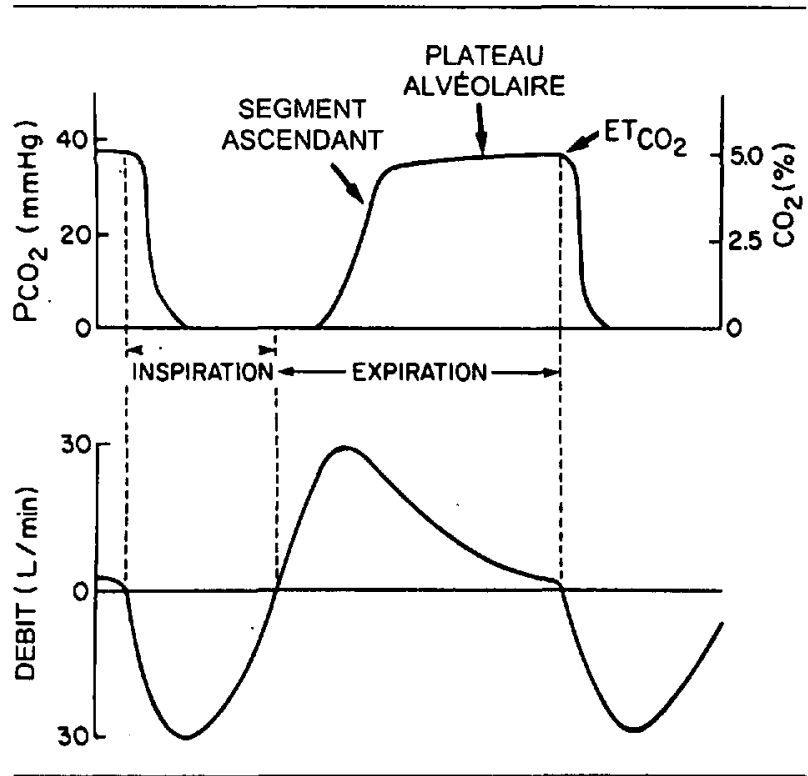

FIGURE Enregistrement simultané de la pression du gaz carbonique ou de la concentration (tracé supérieur) et des débits respiratoires (tracé inférieur) pendant un cycle ventilatoire.

1 La présence de $\mathrm{CO}_{2}$ dans le gaz expiré. Elle résulte d'une série de processus physiologiques dont la production métabolique de $\mathrm{CO}_{2}$, son transport au poumon par la circulation et la ventilation alvéolaire.

2 L'absence de $\mathrm{CO}_{2}$ dans le gaz inspiré. Cette caractéristique reflète l'absence de rebreathing et le bon fonctionnement du circuit.

$3 \mathrm{La}$ courbe du $\mathrm{CO}_{2}$ expiratoire avec montée rapide et plateau alvéolaire caractéristique. Ces particularités sont en fonction de la mécanique respiratoire. La montée rapide du tracé dépend d'un débit initial expiratoire suffisant. La configuration pratiquement horizontale du plateau dépend à son tour d'un débit expiratoire adéquat et la vidange à peu près synchrone des différentes régions du poumon.

$4 \mathrm{La}$ pression télé-expiratoire de $\mathrm{CO}_{2}{ }^{*}$. Cette variable quantitative se rapproche des pressions alvéolaires et artérielles de $\mathrm{CO}_{2}\left(\mathrm{PACO}_{2}, \mathrm{PaCO}_{2}\right)$ mais seulement sous certaines conditions.*

Le gradient $\mathrm{PETCO}_{2}-\mathrm{PACO}_{2}$ est faible si le gaz téléexpiratoire prélevé est un échantillon "propre " de gaz alvéolaire mêlé. Cette condition ne se réalise que lorsque le capnogramme affiche un plateau alvéolaire typique. (L'absence de plateau suggère un volume courant faible, la dilution du gaz expiré par les gaz frais et/ou un site de prélèvement trop rapproché de l'interface gaz inspiré/

* Pour la plupart des moniteurs, la pression du $\mathrm{CO}_{2}$ expiré maximale représente la pression télé-expiratoire. A toutes fins pratiques on peut considérer ces expressions comme synonymes. gaz expiré.) La $\mathrm{PETCO}_{2}$ reflète bien la $\mathrm{PaCO}_{2}$ si l'échantillon de gaz expiré provient d'alvéoles idéales (i.e., d'alvéoles ventilées et perfusées) sans contribution de l'espace mort alvéolaire (i.e., d'alvéoles ventilées mais non perfusées). En anesthésie cette condition supplémentaire ne sè réalise que chez les patients de moins de 50 ans, en bonne santé et hémodynamiquement stables; alors la $\mathrm{PeTCO}_{2}$ est légèrement inférieure à la $\mathrm{PaCO}_{2}$ (en deçà de $5 \mathrm{mmHg}$ ). ${ }^{7}$ On ne peut affirmer ceci pour les patients plus âgés, ceux qui souffrent d'affections cardiovasculaires et respiratoires aiguës ou chroniques ou dont la tension artérielle systémique est basse. ${ }^{8,9}$ Dans ces circonstances, le gaz de l'espace mort alvéolaire peut fortement contaminer l'échantillon télé-expiratoire de sorte que la PET $\mathrm{CO}_{2}$ sous-estime la $\mathrm{PaCO}_{2}$ de façon importante.

Quand la $\mathrm{PETCO}_{2}$ s'approche de la $\mathrm{PACo}_{2}$, elle reflète les facteurs qui déterminent la $\mathrm{PACO}_{2}$. A l'état stable, elle est directement proportionnelle à la vitesse de transport du $\mathrm{CO}_{2}$ aux alvéoles $\left(\mathrm{V}_{\mathrm{CO}_{2}}\right)$ et inversement proportionnelle à la ventilation alvéolaire totale $\left(\dot{\mathrm{V}}_{\mathrm{A}}\right)$ :

$\mathrm{PETCO}_{2} \simeq \mathrm{PACO}_{2}=\mathrm{k} \cdot \frac{\dot{\mathrm{V}}_{\mathrm{CO}_{2}}}{\dot{\mathrm{V}}_{\mathrm{A}}}$

(où \& $\mathrm{k}$ » est une constante proportionnelle)

En état d'instabilité, quand la $\dot{\mathrm{V}} \mathrm{CO}_{2}$ ou la $\dot{\mathrm{V}}_{\mathrm{A}}$ change ou vient de changer, cette relation quantitative ne tient plus.

\section{Le capnogramme anormal}

Trois anomalies générales du capnogramme peuvent signaler une complication critique. Chacune d'elles est en rapport avec les particularités décrites plus haut. Il faut bien comprendre en quoi elles consistent, leur signification physiologique et leurs causes (Tableau I).

1 L'absence de $\mathrm{CO}_{2}$ dans le gaz inspiré. Cette anomalie signifie linsuffisance ou l'absence de circulation et/ou de ventilation alvéolaire efficaces. Pendant l'anesthésie, elle est ordinairement due à un accident technique, comme l'intubation de l'oesophage et le débranchement du circuit, ou ventilatoire, comme l'apnée ou l'obstruction respiratoire. Elle survient aussi pendant l'arrêt cardiaque.

2 La présence de $\mathrm{CO}_{2}$ dans le gaz inspiratoire. $\mathrm{Le} \mathrm{CO}_{2}$ dans le gaz inspiré apparait lorsqu'on initie le rebreathing de façon délibérée (par exemple, le système Mapleson D comme le circuit Bain). Quand le $\mathrm{CO}_{2}$ apparait de façon ou en quantité inattendues, il signale un rebreathing dû au mauvais fonctionnement du circuit anesthésique, tel que l'incompétence d'une valve, l'épuisement de l'absorbeur de $\mathrm{CO}_{2}$ ou l'insuffisance du débit de gaz frais du système Mapleson $\mathrm{D}$.

3 Lïrégularité de la courbe de $\mathrm{CO}_{2}$ expiratoire. La ralentissement du segment ascendant signale une baisse du débit expiratoire causée par une obstruction haute des voies respiratoires ou un bronchospasme. Une aug- 
TABLEAU I Le capnogramme anormal

\begin{tabular}{|c|c|c|}
\hline Anomalie & Signification physiologique & Causes possibles \\
\hline 1 Absence de $\mathrm{CO}_{2}$ expiré & Pas de ventilation et/ou circulation efficace & $\begin{array}{l}\text { Intubation oesophagienne } \\
\text { Débranchement du circuit } \\
\text { Apnée } \\
\text { Obstruction respiratoire complète } \\
\text { Arrêt cardiaque }\end{array}$ \\
\hline 2 Présence de $\mathrm{CO}_{2}$ inspiré & Rebreathing du gaz expiré & $\begin{array}{l}\text { Valves incompétentes } \\
\text { Chaux sodée épuisée } \\
\text { Débit de gaz frais insuffisant dans le Mapleson A,D ou E }\end{array}$ \\
\hline $\begin{array}{l}3 \text { Forme d'onde difforme } \\
\text { a) Segment ascendant prolongé }\end{array}$ & Débit expiratoire diminué & $\begin{array}{l}\text { Obstruction respiratoire partielle } \\
\text { Bronchospasme }\end{array}$ \\
\hline b) Pente du plateau plus aiguë & Asynchronisme de la vidange pulmonaire & $\begin{array}{l}\text { MPOC } \\
\text { Bronchospasme }\end{array}$ \\
\hline $\begin{array}{l}4 \text { Déviation de la } \mathrm{PETCO}_{2} \\
\text { a) } \mathrm{PPETCO}_{2}\end{array}$ & $\begin{array}{l}\text { IVentilation alvéolaire } \\
\text { ITransport du } \mathrm{CO}_{2}\end{array}$ & $\begin{array}{l}\text { Hypoventilation } \\
\text { Hyperthermie maligne } \\
\text { Absorption du } \mathrm{CO}_{2} \text { pendant laparascopie } \\
\text { Administration de bicarbonate* } \\
\text { Dégonflement du garrot* }\end{array}$ \\
\hline b) $\mathrm{IPETCO}_{2}$ & $\begin{array}{l}\text { IVentilation alvéolaire } \\
\text { ITransport du } \mathrm{CO}_{2}\end{array}$ & $\begin{array}{l}\text { Hyperventilation } \\
\text { Hypothermie } \\
\text { Défaillance circulatoire à bas débit } \\
\text { Embolie pulmonaire }\end{array}$ \\
\hline
\end{tabular}

*Elévation transitoire de la $\mathrm{PETCO}_{2}$ seulement

mentation du degré de la pente du plateau alvéolaire peut résulter de la vidange inégale pulmonaire par MPOC ou bronchospasme. Les modifications de la courbe typique ne sont nécessairement pathologiques, v.g., on voit un tracé irrégulier ou tronqué lorsque la respiration est superficielle pendant la ventilation au masque; un plateau alvéolaire en dos de chameau sous ventilation mécanique en décubitus latéral; des oscillations cardiogéniques de la fréquence respiratoire lente et la " bosse du Bain " avec le circuit du même nom.

4 Les déviations de la PetCO . Quand la $\mathrm{PETCO}_{2}$ est proche de la $\mathrm{PACO}_{2}$, la montée progressive de la $\mathrm{PETCO}_{2}$ suggère soit une hypoventilation alvéolaire ou une augmentation de l'arrivée du $\mathrm{CO}_{2}$ aux alvéoles comme dans l'hyperthermie maligne (voir plus haut). Au contraire, une baisse progressive annonce une hyperventilation alvéolaire ou un syndrome circulatoire de bas débit. Une réduction subite de la $\mathrm{PETCO}_{2}$ traduit une interruption soudaine du transport de $\mathrm{CO}_{2}$ aux alvéoles par embolie pulmonaire.

\section{La valeur du capnogramme pour détecter les situations critiques}

Le fait qu'un capnogramme puisse signaler une complication grave ne lui accorde pas nécessairement une valeur diagnostique. Son utilité diagnostique dépend 1) de sa sensibilité à détecter une complication (définie comme la proportion des malades affichant la caractéristique capnographique de cette complication), 2) de sa spécificité (la proportion sans complication qui ne montre pas la caractéristique capnographique), 3) du moment de son apparition (la rapidité avec laquelle la caractéristique se développe) et 4) sa valeur diagnostique ajoutée (sa capacité diagnostique additionnelle et supérieure aux méthodes usuelles). Tout en ayant peu de données de valeur sur la détection d'anomalies spécifiques par le capnogramme, on peut raisonnablement tirer des conclusions en ce qui a trait à la sensibilité, la spécificité etc. de la capnographie et les appliquer à certaines complications. Nous examinerons les complications graves causées par un matériel anesthésique défectueux et les anomalies ventilatoires, circulatoires et métaboliques (Tableau II).

\section{Lintubation oesophagienne}

L'absence d'un tracé typique de $\mathrm{CO}_{2}$ expiratoire est un indicateur très sensible de cet incident. La forme d'onde aberrante qui apparaît de façon transitoire avec la ventilation oesophagienne ne peut être considéré comme typique. ${ }^{10}$ De plus l'apparition de ce signal est immédiate. Ce qui lui manque est la spécificité diagnostique, parce que d'autres conditions abolissent le signal du $\mathrm{Co}_{2}$ expiratoire (par exmple le débranchement du circuit, le bronchospasme grave à l'intubation, une défectuosité de l'analyseur). Comme les autres signes de l'intubation 
TABLEAU II Valeur du capnogramme dans la détection des complications

\begin{tabular}{|c|c|c|c|c|}
\hline Complication & Capnogramme & Sensibilité/Spécificité & Moment d'apparition & Valeur diagnostique ajoutée \\
\hline \multicolumn{5}{|l|}{ Matériel } \\
\hline Intubation oesophagienne & Pas de $\mathrm{CO}_{2}$ expiratoire & Elevée/Basse & Immédiat & Elevée \\
\hline Débranchement du circuit & Pas de $\mathrm{CO}_{2}$ expiratoire & Elevée/Basse & Immédiat & $\begin{array}{l}\text { Modérée (alternative de } \\
\text { secours) }\end{array}$ \\
\hline Rebreathing indésirable & $\mathrm{CO}_{2}$ inspiratoire & Elevée/Elevée & Immédiat & Elevée \\
\hline \multicolumn{5}{|l|}{ Ventilation } \\
\hline Apnée, obstruction complète & Pas de $\mathrm{CO}_{2}$ expiratoire & Elevée/Basse & Immédiat & $\begin{array}{l}\text { Modérée (alternative de } \\
\text { secours) }\end{array}$ \\
\hline Obstruction partielle & Segment ascendant prolongé & Modérée/? & Immédiat & Basse \\
\hline Hypoventilation & $1 \mathrm{PETCO}_{2}$ & Elevée/Modérée & Précoce & Elevée \\
\hline \multicolumn{5}{|l|}{ Circulation } \\
\hline Arrêt cardiaque & Perte rapide du $\mathrm{CO}_{2}$ expiré & Elevée/ Basse & Immédiat & Basse \\
\hline Syndrome de bas débit & $\mathrm{PETCO}_{2}$ & Modérée/Modérée & Précoce & Basse \\
\hline Embolie gazeuse & IPETCO $_{2}$ subite & Elevée/Elevée & Immédiat & Élevée \\
\hline \multicolumn{5}{|l|}{ Mérabolisme } \\
\hline Hyperthermie maligne & $\mathrm{IPETCO}_{2}$ rapide & Elevée/Modérée & Précoce & Elevée \\
\hline
\end{tabular}

N.B. Les estimations de la sensibilité/spécificité et de la valeur diagnostique ajoutée sont celles de l'auteur.

oesophagienne sont à l'occasion vagues ou retardés, ${ }^{11}$ la valeur diagnostique ajoutée est élevée.

\section{Le débranchement du circuit}

La perte du signal du $\mathrm{CO}_{2}$ expiratoire est un signe immédiat et très sensible, mais encore là non spécifique d'un débranchement de circuit. Comme l'observation et une alarme de basse pression du circuit révèle ce problème rapidement et avec fiabilité, la valeur ajoutée du capnogramme le place en deuxième ligne, comme alternative de réserve. ${ }^{12}$

\section{Le rebreathing}

La présence de $\mathrm{CO}_{2}$ inspiratoire en quantité anormale est un signe spécifique, sensible et immédiat du rebreathing - bien qu'il ne soit pas spécifique à une étiologie particulière (Tableau I). Mais aucun signe clinique ou autre moniteur ne peut détecter le rebreathing aussi bien. Donc la valeur diagnostique ajoutée est élevée.

\section{L'apnée et l'obstruction respiratoire complète}

La perte du signal de $\mathrm{CO}_{2}$ expiré est un signe sensible, immédiat mais non spécifique de ces deux événements. Comme on peut les détecter par l'observation clinique ou les alarmes de pression pendant la ventilation mécanique, on considère la valeur ajoutée du capnogramme comme une alternative de deuxième ligne.

\section{Lhypoventilation}

Quand on peut considérer la $\mathrm{PETCO}_{2}$ comme équivalente à la $\mathrm{PACO}_{2}$ et à la $\mathrm{PaCO}_{2}$, une augmentation progressive de son niveau est un indice très sensible, modérément spécifique et rapidement évident d'une insuffisance ventilatoire. Quand la $\mathrm{PETCO}_{2}$ est éloignée de la $\mathrm{PACO}_{2}$, sa sensibilité et sa spécificité diminuent. Comme les indices cliniques d'une hypoventilation ne sont ni sensibles, ni spécifiques, la valeur diagnostique ajoutée est élevée.

\section{L'arrêt cardiaque}

Une baisse rapide de la $\mathrm{PETCO}_{2}$ et la perte du signal de $\mathrm{CO}_{2}$ expiré sur une période d'environ 30 secondes est indicative d'un arrêt cardiaque. Cependant, cet événement devrait être détecté de manière plus spécifique et plus rapide par d'autres moyens. Dans ce contexte, la $\mathrm{PETCO}_{2}$ a plus de valeur comme moniteur non invasif de l'efficacité des compressions précordiales pendant la réanimation. Dans ces conditions, le niveau de $\mathrm{PETCO}_{2}$ correspond à l'importance du débit cardiaque (en réalité la vitesse de transport du $\mathrm{CO}_{2}$ vers le poumon). ${ }^{.13}$

\section{L'embolie gazeuse}

Une réduction subite de la $\mathrm{PETCO}_{2}$ est un indice très sensible, spécifique et immédiat d'embolie gazeuse. Cette réduction représente un indice beaucoup plus sensible que les signes cardiovasculaires usuels (ITA, IPVC et mod- 
ifications de l'ECG) et plus approprié que le très sensible Döppler. ${ }^{14}$ Par conséquent sa valeur diagnostique ajoutée est élevée.

\section{Lhyperthermie maligne}

Une augmentation rapide de la $\mathrm{PETCO}_{2}$ est un indice sensible et précoce qui précède la poussée hyperthermique et autres signes cliniques. ${ }^{5,16}$ Cet indice n'est pas très spécifique car l'hypoventilation peut aussi faire monter la $\mathrm{PETCO}_{2}$, mais on peut facilement régler le problème de l'hypoventilation. Sa valeur diagnostique ajoutée est donc élevée.

A partir de l'analyse de ces événements critiques, on peut déduire que le monitorage du $\mathrm{CO}_{2}$ dans les voies respiratoires a sa plus grande valeur comme détecteur de l'intubation trachéale, des défectuosités du circuit anesthésique qui provoquent le rebreathing, de l'hypoventilation, de l'embolie gazeuse et de l'hyperthermie maligne. $\mathrm{Ce}$ monitorage peut être aussi un détecteur de deuxième ligne des débranchements de circuits, de l'obstruction respiratoire complète et de l'apnée. Malgré tous ces bénéfices reconnus, on n'a pas encore fait la preuve que le monitorage du $\mathrm{CO}_{2}$ prévient les séquelles néfastes de ces événements, comme la lésion hypoxique et la mort, et modifie le pronostic anesthésique.

\section{Autres applications cliniques}

Deux caractéristiques du capnogramme, la forme d'onde expiratoire et la $\mathrm{PETCO}_{2}$ peuvent être utiles sous d'autres aspects.

Le monitorage de la forme d'onde $\mathrm{du} \mathrm{CO}_{2}$ peut aider à identifier des incidents ventilatoires non critiques comme l'apparition d'un l'effort respiratoire pendant la ventilation mécanique et la variation du pattern ventilatoire en respiration spontanée. L'observation de la forme d'onde pourrait même faciliter l'intubation nasale à l'aveugle. ${ }^{4}$

Le monitorage de la $\mathrm{PETCO}_{2}$ peut simplifier et améliorer le contrôle de la $\mathrm{PaCO}_{2}$ dans plusieurs situations: 1) l'initiation et le maintien de l'apnée pour la ventilation mécanique, 2) le sevrage du ventilateur, 3) la compensation des déséquilibres acidobasiques et 4) le traitement de l'hypertension intracrânienne. Quand une différence importante entre $\mathrm{PETCO}_{2}$ et $\mathrm{PaCO}_{2}$ est suspectée, on peut mesurer directement la différence $\mathrm{PETCO}_{2}-\mathrm{PaCO}_{2}$.

\section{Conclusion}

Le monitorage du $\mathrm{CO}_{2}$ respiratoire représente pour l'anesthésiste un système d'alarme précieux et capable de détecter une gamme étendue de complications éventuelles graves. Comme détecteur de plusieurs de ces complications, il est à la fois sensible et rapide, mais non spécifique, ni diagnostique. Par conséquent, les données recueillies par le monitorage du $\mathrm{CO}_{2}$ (comme celles de tout autre moniteur) doivent toujours être interprétées dans un contexte clinique et évaluées avec les autres informations pertinentes.

\section{Références}

(Voir page R44). 